about the validity of an entry in a published table that showed a 10 per cent immunofluorescence assay of a cultured clone, whereas the relevant notebook included the legend "very few cells positive", the investigation does not accept Popovic's claim that he had read the data separately from his colleague, and that the published data were averages of the two datasets. With a trace of irony, the report says that "he noted that he unfortunately could not adduce written documentation", and concludes that the treatment of this one datum constitutes misconduct.

- On three allegations about a table representing data gathered in an investigation of the reactions of individual patients to particular assays, the investigation rejects two, but says that the legend N.D. was used to conceal awkwardly negative results, and thus constitutes misconduct.

One of the most contentious issues in the report is the origin of the T-cell line called HUT-78, now acknowledged to have been established by Dr Adi Gazdar. The earlier inquiry had concluded that Gazdar had not been given credit for his work, and that the origin of the cells had been obscured by a change of nomenclature and by the incorrect description of the line as having originated in a patient with lymphoid leukaemia. A related issue is whether a letter in the The Lancet in December 1984 with Gallo and Popovic as two of three authors misrepresented three cell lines as different when, in reality, they were all derived from HUT-78.

The investigation says that the issue became more important as its work went on, chiefly because of the confusion about the origin of the cells. The report says "it is astonishing" that, in the letter in The Lancet, "Dr Popovic used and reported on a cell line which he still has not been able to identify with certainty".

The investigation was plainly offended by the conflict of the evidence from Popovic and Gallo that "they could not identify the source of the HT cell line any more precisely than they had reported" when early drafts of the disputed paper, including one in Popovic's handwriting, "fully and accurately identified the source as a patient with Sezary Syndrome".

The investigation is also critical of Popovic for having submitted the Lancet letter referring to three supposedly distinct cell lines when he "knew or should have known" of their common origin.

On at least two occasions, the investigation reports that Popovic was instructed by Gallo to investigate the origin of the cell line; the investigation complains that he was "negligent in failing to ensure the accurate conduct and reporting of research". The investigation says its members did not arrive at a consensus on the question whether the objective was to disguise the origin of the cell line in which HIV was eventually grown. The investigation concludes with a listing of 20 instances of "knowledgeable NATURE · VOL 357 • 14 MAY 1992

\title{
Gallo and Popovic lawyers reply
}

In letters to Bernadine Healy, director of the US National Institutes of Health (NIH), attomeys for Robert C. Gallo and Mikulas Popovic take exception to certain conclusions in the draft "final" report from the NIH Office of Scientific Integrity (OSI).

Joseph N. Onek, who represents Gallo, takes issue, for instance, with the suggestion that "the results of the sequencing [of virus samples from 1983 and 1984] will shed additional light" on the allegation that the French virus was "misappropriated". Much of the sequencing is complete already.

In a letter dated 11 February 1992, Onek writes: "What is the possible basis for the belief that the results of the sequencing will shed additional light on the matter? This is truly a self-serving statement by the OSI to justify its expensive sequencing efforts and to avoid the obvious conclusion that any contamination was accidental. The statement is pemicious because it leaves open an issue which should be closed."

Onek also challenges OSI's conclusions about the origins of the HUT-78 cell line which Popovic cloned to obtain a cell line he called H9. In the conclusion of its report. OSI claims that Gallo "misrepresented" the origins of the H9 cell line. Onek says: "This charge is also inconsistent with the body of the report. The report never states that Dr Gallo misrepresented the origins of H9 ..... Moreover, he and Dr Popovic made the $\mathrm{H} 9$ cell line available to researchers throughout the world and Dr Popovic published the HLA phenotype of H9 in 1985 ... Despite these facts, and despite the extensive efforts made by Dr Gallo and Dr Popovic to find the origins of H9, the reports suggests that Dr Gallo should have done still more. The OSI seems unaware that millions of people are dying of AIDS and that both Dr Gallo and Dr Popovic had higher priorities .... Dr Gallo never claimed to have developed $\mathrm{H} 9$ himself and gained nothing by the confusion as to its origins.

Popovic is represented by attomey Barbara F. Mishkin who, like Onek, challenges the OSI's handling of the allegation of misappropriation. In a letter to NIH director Healy dated 13 February 1992, Mishkin writes: "We specifically request that OSI address, and lay firmly to rest, suggestions ... that our client stole, or misappropriated, the French virus.

"Inasmuch as the sequencing report demonstrates that every identifiable virus that our client put into his 'pool' was a novel virus (that is, neither LAV nor LAI), it is clear that he did not 'use' the French virus to establish his continuous culture. That Popovic's pooled culture and the Institut Pasteur's LAV/BRU were both subsequently contaminated by LAI was unknown at the time the Science papers were published and refutes assertions of intentional misappropriation. In all fairness, NIH should make this clear.

"It is equally important to emphasize that research on the cutting edge cannot always be as precise and carefully planned as one would like. Despite the trivial and unintended inaccuracies, the central finding of Popovic et al. remains valid and his reagents (virus-expressing cell lines) are widely used even today."

The OSI report is now in the hands of James Mason, the assistant secretary for health in the Department of Health and Human Services, of which NIH is a part. It is now up to Mason to issue a final opinion after evaluating the report and the rebuttals.

misreporting or errors" which, it says, is an inordinate number for a paper only three and a half pages long. Acknowledging that some are merely drafting errors, it says that eight constitute scientific misconduct. "Taken together", the report says, "these errors represent evidence of a level of haste and error that cannot be condoned." The report is also critical of the editorial handling of the four manuscripts, saying that "many of the errors of ambiguity and inconsistency" should have been discovered before publication.

Plainly the investigation does not wholeheartedly follow the authors' defence that a blood-test was necessary for screening blood used in the treatment of haemophiliacs, that delay in publication might hazard the chance of securing patent protection and that there was in any case political pressure to publish quickly from the Department of Health and
Human Services." The investigative team was not convinced that the speed of preparation, whatever the reason, made the knowing misrepresentations inevitable or excusable".

The investigation's recommendations on Gallo are that he should be held directly responsible for four minor discrepancies out of the total 20 , and that "he breached his overall responsibility ... to ensure the accuracy of the paper", but that this does not constitute misconduct. The report says that the outside advisers were split two to one on this recommendation, with the odd person holding that "Dr Gallo's negligent conduct coupled with his apparent disregard in this instance for accuracy and responsibility in the conduct and reporting of scientific research, did constitute misconduct".

John Maddox 